\title{
Systemic-onset juvenile idiopathic arthritis
}

\author{
INSERM
}

\section{Source}

INSERM. (1999). Orphanet: an online rare disease and orphan drug data base. Systemiconset juvenile idiopathic arthritis. ORPHA:85414

Systemic-onset juvenile idiopathic arthritis is marked by the severity of the extra-articular manifestations (fever, cutaneous eruptions) and by an equal sex ratio. 